\title{
Additions to the Floral List of the Cypress Hills in Saskatchewan
}

\author{
By JOHN HOWARD HUDSON, Regina
}

During a trip to the Cypress Hills made by Dr. G. F. Ledingham and myself from May 30 to June 2, three species not earlier listed for the Hills were turned up. (Later June 26 to 29 - I came back alone for older material.) The standard list is of course that of Breitung (1); it gives one an excellent notion of the plants one is likely to see in this region.

The new plants are:

(1) Woodsia oregana D. C. Eaton. Found May 31, 1956, on a dry juniper-covered slope just below the edge of the bench in the West Block, location probably S.E. $1 / 4 \quad 36-7-29$ W 3rd. Also on June 27, on N.E. $1 / 4$ 25-7-29 W 3rd. To get here, take the Fort Walsh trail south-west from Maple Creek, turn off through the Six-Mile Ranch, and climb the mountain trail up from the ranch to the edge of the bench. This Woodsia is a small tufted fern, when young having a most deceptive resemblance to ferns with the frond edges reflexed to cover the marginal sori. Elsewhere in Saskatchewan it occurs in the Precambrian, and has been reported from there by Fraser and Russell (4).

This Woodsia oregana was later seen in the Center Block on June 2, on N.W. 1/4 5-8-26 W 3rd, growing with Saxifraga rhomboidea in and around cobblestone strips in the valley of Weaver Creek just south of the Park.

(2) Lithophragma bulbifera Rydb. Found in bottoms of moist springy draws, side ravines of Weaver Creek in N.W. $1 / 4 \quad 5-8-26$ W 3rd. To get here, take the road from the Park Headquarters to the golf course, but instead of turning into the latter place, drive on out of the Park about $11 / 4$ miles. This small saxifrage is described in Budd (2), who reports it as occurring on "dry hills but very uncommon ... in the extreme south of the area." Fraser and Russell (4) report it from Robsart. These reports, which may well be based on the same collections, may refer to the southern margin of the Cypress Hills, but Breitung did not report the plant.

(3) Lomatium montanum Coult \& Rose. Found on submontane prairie on slopes (not on the bench proper), east face of the West Block of the Cypress Hills, S.E. 1/4 36-7-29 W 3rd, May 31,1956 . Altitude $4,300 \mathrm{ft}$. Fruit collected in the same place June 27. Quite ccmmon on moist prairie. In flower this plant resembles closely our common Musineon divaricatum, as a dwarf carrot with yellow flowers. The celery taste and smell of all parts of our plant will distinguish it from Musineon. Its fruit is much like that of other members of the genus. With lateral ribs well winged, 8-10 $\mathrm{mm}$. long, oval in shape. No previous reports of this plant exist for Saskatchewan to my knowledge. Davis (3) gives the range as W. Mont. to N. Idaho, south to W. Wyo. and Oreg.

Specimens will be sent to the herbarium of the Department of Agriculture in Ottawa, and to that of Dr. R. C. Russell at the Dominion Laboratory of Plant Pathology in Saskatoon. This distribution will not occur till fall, when one works over the collections of the summer.

\section{LITERATURE CITED}

A. J. BREITUNG - A Botanical Survey of the Cypress Hills. The Canadian Field-Naturalist, Vol. 68, No. 2, pp. 55-92, April-June 1954 .

A. C. BUDD - Plants of the Farming and Ranching Areas of the Canadian Prairies. p. 130. Experimental Farms Service, Department of Agriculture, Ottawa, 1952.

R. J. DAVIS - Flora of Idaho. p. 515. Wm. C. Brown \& Co., Dubuque, Iowa, 1952.

W. P. FRASER and R. C. RUSSELL - An annotated List of the Plants of Saskatchewan. 3rd edition. University of Sáskatchewan, Saskatoon, 1954. 